\title{
Is THIS A PUBLIC LAW CASE?
}

\author{
Andrew S Butler*
}

This article is a revised and updated version of a paper presented at the New Zealand Law Society Intensive on Public Law in September 1998. In it, Andrew Butler demonstrates the breadth of the concept of "public law" by investigating the application provision of the New Zealand Bill of Rights Act 1990 and the field of activity susceptible to public law judicial review. He concludes that nowadays a public law case can arise in settings (such as the formulation of common law private law, the interpretations of statutory private law, commercial contracts of public entities, regulatory acts of private bodies) far removed from those traditionally thought of as public law ones.

\section{INTRODUCTION}

Is this a Public Law Case? Such a seemingly simple question, yet one which is very difficult to answer. One of the prime reasons for this difficulty is that our notions of public law and its analogue, private law, are poorly developed. To many of us, the basic working concept is that private law is the law of torts, contracts, restitution, equity and so on, with a primary (though far from exclusive) focus on monetary remedies, while public law is constitutional and administrative law with a primary focus on the remedies related to judicial review. ${ }^{1}$ Yet a moment's reflection will indicate that even as a working concept this view is flawed. ${ }^{2}$

For example, the tort liability of public authorities, while analysed within the framework of the "private law" of tort, is significantly shaped by public law

* Senior Lecturer, Faculty of Law, Victoria University of Wellington, and currently of the Crown Law Office, Wellington. The author gratefully acknowledges the assistance of colleagues at Bell Gully Buddle Weir, Wellington (where he was Law Faculty Research Fellow, 1998-1999) in the preparation of the original paper, and Janet McLean for her comments on an earlier version of the paper. Thanks are also due to the New Zealand Law Society for permission to reproduce large parts of the paper originally prepared for the Society's Public Law Intensive in September 1998.

1 See G Hogan and D Morgan Administrative Law in Ireland (2 ed, Sweet \& Maxwell, London, 1991) 319.

2 Hogan and Morgan, above n 1, 319 note that private law applies in appropriate contexts to government. 
considerations. ${ }^{3}$ In contract law, similar developments are underway: there appears to be emerging in New Zealand a public law of tendering while overseas a complex interaction between fiduciary duties, contract and public regulatory law is occurring in the financial services sector. ${ }^{4}$ In relation to equity, chapters are beginning to appear in textbooks reflecting the fact that though government is affected by rules and principles of equity, the application of those rules and principles is so affected by the public law context that separate treatment is required. ${ }^{5}$ Thus, it is fair to say that there is within the heartland of private law, a public law of negligence, a public law of contract, a public law of equity. In the other direction, however, "private law" appears to have invaded the realm of public law. ${ }^{6}$ Thus, while the authors of the chapter in McGechan on Procedure on the Judicature Amendment Act have argued that "an implicit requirement in section 4(1) [of the 1972 Act as amended] is the presence of some public element" they have had to accept that "New Zealand cases may be found which are inconsistent with this analysis" including cases concerning the implication of natural justice rights into the contractual or similar arrangements of domestic bodies. ${ }^{7}$

Bearing in mind the lack of success of other commentators in rendering a wholly satisfactory definition of public law, I hope that I will be forgiven if I adopt a rather simple, rough and ready, framework within which to discuss the question, Is this a Public Law Case? What I want to do is concentrate on determining in what circumstances we can say that a particular case is such that public law considerations operate so as to influence the substantive content of the law which is to govern. Due to limitations of space I have decided that we can take it that public law considerations will be involved if the case is

3 See M Allars "Tort and Equity Claims Against the State" in P D Finn (ed) Essays on Law and Government Vol 2 The Citizen and the State in the Courts (Law Book Company, Sydney, 1996) ch 3; J Doyle and J Redwood "The Common Law Liability of Public Authorities: the Interface between Public and Private Law" [1999] Tort L Rev 30; R Harrison, "'Converting it into Cash:' Compensation and Damages in Public Law" in NZLS Public Law Intensive 1998 (NZLS, Wellington, 1998); S Kneebone Tort Liability of Public Authorities (Law Book Company, Sydney, 1998) especially ch 1 .

4 See J Beatson "The Relationship between the Regulations Governing the Financial Services Industry and Fiduciary Duties under the General Law" in E McKendrick (ed) Commercial Aspects of Trusts and Fiduciary Obligations (Clarendon Press, Oxford, 1992).

5 See G Dal Pont and D Chalmers Equity and Trusts in Australia and New Zealand (Law Book Company, Sydney, 1996) ch 4; A S Butler "Equity \& Public Law" in A S Butler (ed) Equity \& Trusts in New Zealand (Brooker's, Wellington, forthcoming); Allars, above $\mathrm{n} 3$.

6 See also D Oliver "Common Values in Public and Private Law and the Public/Private Divide" [1997] PL 630.

7 Hon Robert McGechan (ed) McGechan on Procedure (Brookers, Wellington, 1988) para JA4.04 (updated 7 November 1997). 
one which is subject to the Bill of Rights and/or the subject of public law judicial review. The rest of this paper is aimed at determining when a case is subject to the Bill of Rights and/or the subject of public law judicial review. The approach will be principally doctrinal, as opposed to theoretical (though, of course, theory will have a role to play) with the aim of demonstrating what sorts of cases in your practice are likely to be ones in which public law considerations will be relevant.

As we shall see, in some circumstances public law considerations will be implicated because of the identity of the actor, while in others the focus will rather be on the underlying nature of the function, power, duty and so on which is in issue. And these two need not be mutually exclusive.

At a general level we should not be surprised that the trigger for "Public Law" may take the form of both the identity of the actor (often referred to as the "source" test) and the nature of the power, duty or function (the "function" test). On the one hand, governmental institutions are regarded differently from private persons (legal or natural). More particularly, in the modern age the standards of propriety and accountability which are demanded of government are often much higher than those demanded of private persons. Government is meant to be a model citizen in all its activities. At the same time though, there is a greater reticence to restrict governmental freedom to manoeuvre, at the policy level at least, in the belief that that will only reduce responsiveness to the electorate. For both reasons, the identity of the actor (is it a public/governmental institution or a private one?) is obviously a significant issue in determining what standards it must adhere to. On the other hand, the need for a functional test is also obvious. Functions which are carried on for the benefit of and/or in the interests of the public (and one has to admit that the meaning of these phrases is inexact) and which are of a particular public importance (either intrinsically, or because of the way in which they are supplied or made available to the public for example monopoly, oligopoly, and so on, or both) should be governed by the same set of standards irrespective of the identity of the actor. The processes of corporatisation, privatisation and contracting-out have forced public lawyers to rediscover ${ }^{8}$ the importance of the nature of the function as a core aspect of public law, reminding us that, in relation to some activities, public law should have an input regardless of the identity of the actor. ${ }^{9}$

8 I say rediscover, because even before the advent of big government, the law had recognised in various ways that functions which affected the public interest required a special set of standards not generally required of private law. See for example the law of common carriers.

9 A similar sentiment is expressed by Lord Woolf of Barnes "Droit Public-English Style" [1995] PL $57,63-64$. 
Two final points. First, one important theme of this paper is that the scope of public law properly extends well beyond the traditional scope associated with judicial review. In particular, in exploring the application of the New Zealand Bill of Rights Act I have attempted to underscore the point that public law has much to say about many aspects of the substantive rules of private law, be they found in statute or common law.

Second, answering the question, Is this a Public Law case? merely satisfies an initial threshold question. It is designed to determine whether public law standards may legitimately be brought to bear on the analysis of the case: it does not necessarily determine the exact content of those standards. No doubt being able to say that a case is a public law case will assist in narrowing down the options or in indicating the likely type of standards. But the intensity of those standards will be determined by reference to the individual circumstances, the gravity of the issue and the nature of the decision-maker. ${ }^{10}$

With this background in mind, let us attempt to analyse what cases fall within the ambit of the New Zealand Bill of Rights Act 1990 and of public law judicial review.

\section{THE NEW ZEALAND BILL OF RIGHTS ACT 1990}

Most lawyers would readily accept that the Bill of Rights is a public law document, ${ }^{11}$ setting standards to govern the activities of government and those bodies performing public functions. Yet as we shall see presently, a full consideration of the application provision of the Bill of Rights indicates that "public law" has a very wide ambit and, ironically, is of direct relevance to significant parts of private law.

10 See Electoral Commission v Cameron [1997] 2 NZLR 421, 430 (CA); Waitakere City Council v Lovelock [1997] 2 NZLR 385, 403 per Thomas J, 419 per Blanchard J (CA); $R v$ Secretary of State for the Home Dept, ex p Bugdaycay [1987] 1 All ER 940, 952 per Lord Bridge (HL). See also J Hodder, "'Irrationality': a Synonym Too Far" in NZLS Public Law Intensive 1998 (NZLS, Wellington, 1998). This point is helpfully discussed in Wandsworth LBC v A [2000] 1 WLR 1246 (CA) where it was held that a parent has a public law right not to be excluded from school grounds without the observance of natural justice. Buxton LJ for the Court of Appeal warned (at 1253-1254) against the heresy

that once a case is found to fall into the category of "public law" duty, that duty must be of the same nature and intensity in any case where public law is engaged. ..."[T]he actual terms of [natural justice duties], and in particular the duty to hear submissions, will be strongly affected by the nature of the public body and the demands of the public work that it performs".

11 Certainly a key feature of the Court of Appeal's decision in Baigent's Case (Simpson v AttorneyGeneral) [1994] 3 NZLR 667 (CA) that compensation could be claimed for a violation of the Bill of Rights and was not barred by s 6(5) of the Crown Proceedings Act 1950 immunity from tort was that the Bill of Rights is a "public law" document: 677 per Cooke P, 691 per Casey J, 718 per McKay $\mathrm{J}$. 


\section{A The Application Provision}

Section 3 of the Bill of Rights Act reads:

3 Application - This Bill of Rights applies only to acts done-

(a) By the legislative, executive, or judicial branches of the government of New Zealand; or

(b) By any person or body in the performance of any public function, power, or duty conferred or imposed on that person by or pursuant to law.

\section{Section 3(a)}

Let us examine section 3(a) first. By that sub-section, acts of the legislative, executive and judicial branches of the government of New Zealand fall within the scope of Bill of Rights scrutiny. A number of points should be made about this provision.

\section{(a) Section 3(a) captures outputs as well as processes}

The first point to be made about section 3(a) is that the processes and procedures of the three branches referred to are intended to be regulated by the Bill of Rights: they are acts of those institutions and also provide the framework within which other acts of those institutions take place. But the Bill of Rights extends much further, governing the output of each of the three institutions. Thus, section 3(a) governs not only Parliamentary proceedings, ${ }^{12}$ but also the content of legislation. ${ }^{13}$ Similarly, the content of executive acts such as circulars, policies, and individual executive acts as well as the processes of the executive fall within the scope of the Bill of Rights. Finally, by the same reasoning, not only the way in which courts (and tribunals) conduct themselves must meet the requisite Bill of Rights standards, ${ }^{14}$ but so also must the output of the courts in the course of adjudicating upon disputes, including naturally the rules of the common law.

12 P A Joseph "Constitutional Law" [1997] NZ L Rev 209, 225-226 sets out the relevant material. See also D McGee Parliamentary Practice in New Zealand (2 ed, G P Publications, Wellington, 1994) 505506

13 If it were otherwise, there would hardly be a need for the statement in s 4 of the Bill of Rights that enactments which are inconsistent with the Bill of Rights prevail notwithstanding inconsistency with the Bill of Rights, nor for the s 7 procedure under which the Attorney-General must report to Parliament on Bills which are inconsistent with the Bill of Rights.

14 For example, a number of the fair trial rights guarantees are directed at the judicial process in criminal trials: see for example ss 24(b), 25 and 26. In A v Attorney-General Employment Court, WC 1/00, 21 January 2000, 9 Goddard CJ recognised that in determining whether to order name suppression, the Employment Court was subject to the Bill of Rights by virtue of s 3(a) of the Bill of Rights. 


\section{(b) Scope of action caught by section 3(a) greater than that caught by section 3(b)}

Second, in my opinion, the purport of section 3(a) is that all acts of the three branches of government are caught. Thus, in all of the activities of those institutions, from employment policies to core public tasks and functions, the Bill of Rights is a presence. This view is confirmed by a reading of section 3(b). Section 3(b) extends the Bill of Rights to persons or bodies in the performance of any public function. Hence, a body caught by section $3(\mathrm{~b})$ would have to adhere to the Bill of Rights in performing whatever public function it had. Yet outside that field (for example its internal organisation, employment practices, and so on) the Bill of Rights is not directly relevant. ${ }^{15}$ The reverse must be true for those caught by section 3(a).

Moreover, this view of section 3(a) corresponds with the approach adopted by the Supreme Court of Canada under section 32(1) of the Canadian Charter of Rights and Freedoms. While that provision does not have the two limbs of section 3, the Supreme Court has developed a jurisprudence under which it distinguishes between entities which are governmental in character and those which though private may be subject to the Charter if used to implement specific governmental programmes. In the recent Eldridge case, the Court reaffirmed its prior jurisprudence that, "when an entity is determined to be part of the fabric of government, the Charter will apply to all its activities, including those which might in other circumstances be thought of as 'private'"16 whereas when the entity is private it will only be subject to the Charter in relation to those of its activities (if any) which implement specific governmental programmes (this was the position of the hospitals the acts of which were impugned in Eldridge).

15 To similar effect see P Rishworth "The New Zealand Bill of Rights Act 1990: The First Fifteen Months" in Essays on the New Zealand Bill of Rights Act 1990 (Auckland, Legal Research Foundation, 1992) 18. Note, however, that I disagree with Rishworth's view that the purpose of $s$ 3(b) "is plainly to assist in the difficult task of explicating the term 'executive branch' in s 3(a)." In my view, s 3(b) has the separate role of isolating the acts of those persons or bodies not caught by $\mathrm{s}$ $3(\mathrm{a})$, which occur in the performance of a public function. In this way $\mathrm{s} 3(\mathrm{~b})$ may be a supplementary aid to the interpretation of s 3(a), but it is clearly more than that. In their article, "Section 3 of the Bill of Rights" [1997] NZLJ 251, 254, Paul Radich and Richard Best also contest Rishworth's view.

16 Eldridge v Attorney-General of British Columbia (1997) 3 BHRC 137, 153. See also Wijetunga v Insurance Corporation of Sri Lanka [1985] LRC (Const) 335 (statutory corporation held to be emanation of government and disciplinary action aimed at curbing employee's free expression susceptible to constitutional review). 


\section{(c) Defining "the executive"}

Third, in light of the extent to which the scope of application of the Bill of Rights hinges on whether an entity is caught by section 3(a) or section 3(b), the definition of "the executive" for the purposes of section 3(a) has no small importance.

The Supreme Court of Canada has been keen to emphasise that this issue must be answered by reference to substance and form, not form alone. Thus, an entity outside the usual departmental structure will not necessarily escape classification as part of the executive. ${ }^{17}$ The rationale for this approach is that "government should not be permitted to evade their Charter responsibilities by implementing policy through the vehicle of private arrangements." 18

The approach in Canada has been to determine whether the entity is "an emanation of government". ${ }^{19}$ Relevant indicia are whether the entity is under the routine and regular control of the Crown; the extent of its autonomy from government in running its affairs and setting its direction; the appointment of its directors/board and so on. Interestingly, extensive regulation and funding by government has not been regarded as a sufficient basis to classify an entity as an emanation of government if the entity remains essentially autonomous. ${ }^{20}$ Thus, in the university and college cases, the Supreme Court closely examined the factual and legal matrix of control and direction in determining whether employment policies of such bodies were governed by the Charter. ${ }^{21}$

17 See also Agarwal v Gurgaon Gramin Bank AIR (1988) SC 286 (IndSC) (regional rural bank held to be instrumentality of the state and its employment practices had to be conducted in accordance with constitutional fair procedures). See also Gunaratne v People's Bank [1987] LRC (Const) 383, 396 (SriLSC).

18 Eldridge v Attorney-General of British Columbia above n 16, 153.

19 Eldridge $v$ Attorney-General of British Columbia above n 16, 152.

20 Thus, in the hospital case (Stoffman $v$ Vancouver General Hospital [1990] 3 SCR 483 (SCC)) and the university cases (McKinney $v$ University of Guelph [1990] 3 SCR 229 (SCC) and Harrison v University of British Columbia [1990] 3 SCR 451 (SCC)), the Supreme Court found that notwithstanding extensive funding support for their activities the defendant institutions were not part of government for the purposes of s 32. Note though that in Eldridge the Supreme Court made it clear that acts of these institutions to the extent that they gave effect to specific governmental programmes would be caught by the Charter.

21 Thus, in Douglas/Kwantlen Faculty Association v Douglas College [1990] 3 SCR 570 and Lavigne v Ontario Public Service Employees Union [1991] 2 SCR 211 the Supreme Court held that collective employment agreements were subject to Charter review because the colleges involved in those cases were so much under the control and direction of the Crown as to be emanations of government. By way of contrast, see the conclusions reached in McKinney $v$ University of Guelph, above $\mathrm{n} 20$ 
In New Zealand, there has been little appreciation of the different scope of application between section 3(a) and section 3(b), hence little useful analysis of the meaning of the "executive" for Bill of Rights purposes ${ }^{22}$ and, as an inevitable result, confused case law. For example, one would have thought that the acts of law enforcement officials such as police and traffic officers would be regarded as core executive functions. Yet, in several cases, the Bill of Rights has been held to apply through section 3(b), not 3(a). ${ }^{23}$ Indicative of the confusion on the difference between sections 3(a) and 3(b) in this area is that the same judge - Richardson $\mathrm{P}$ - has held in one case that the acts of police officers are caught by section $3(\mathrm{~b})$, and in a later case, by section $3(\mathrm{a}) !^{24}$

On the case law to date, a narrower view of "the executive" appears to prevail in New Zealand than in Canada. In Federated Farmers $v$ New Zealand Post (the Rural Delivery Fee case ${ }^{25}$ McGechan $J$ was required to determine whether an increase in the rural delivery fee (RDF) was an interference with rural dwellers' freedom of expression contrary to section 14 of the Bill of Rights. In holding that New Zealand Post (NZP) was caught by section 3 , his honour stated:

The threshold question is whether NZP falls within section 3. I would not necessarily regard it as part of the "executive" branch of the "government of New Zealand" within section 3(a), given the context provided by section $3(\mathrm{~b})$. The question more naturally arises under section 3(b) itself.

While going on to hold that New Zealand Post was indeed caught by section 3(b), it is implicit in McGechan J's view that once a body is located outside the departmental structure then the most natural way of determining its applicability is to have recourse to section 3(b). This is counter to the Canadian position. ${ }^{26}$ Moreover, it results in a quite narrow meaning being given to the notion of "the executive". It allows the simple expedient of corporatisation to reduce the range of conduct subject to Bill of Rights

22 When the issue comes to be examined, the Court of Appeal's valuable analysis (in the non-Bill of Rights setting of tax law) in CIR $v$ Medical Council of New Zealand [1997] 2 NZLR 297 (CA) the meaning of the phrase "instrument of the Executive Government" will require consideration.

23 See Littlejohn $v$ Ministry of Transport [1990-92] 1 NZBORR 285, 299 (HC); Noort v MOT; Curran v Police [1992] 3 NZLR 260, 282 per Richardson J (CA); Simpson v Attorney-General [Baigent's case] [1994] 3 NZLR 667, 714 per Gault J (CA).

24 Noort $v$ MOT above n 23, 282 (s 3(b)) and $R v N$ [1999] 1 NZLR 713, 718 (s 3(a)).

25 Federated Farmers $v$ New Zealand Post [1990-92] 3 NZBORR 339 (HC).

26 Thus, in Rural Dignity of Canada v Canada Post Corp (1991) 78 DLR (4th) 211, 224-225 it was held that $\mathrm{CPC}$, a Crown Corporation, was part of government, with reference made to its being an agent of the Crown, its being subject to Ministerial direction and its historical status as a governmental department. 
scrutiny. Nonetheless, most later cases appear to have followed McGechan J's lead, analysing impugned acts of State Owned Enterprises (SOEs) and similar enterprises under section 3(b) rather than 3(a). ${ }^{27}$ (These cases will be considered later under section 3(b).)

A possible exception is $M v$ Palmerston North Boys High School. ${ }^{28}$ There, Goddard J in the course of determining that acts related to the private boarding residence of the defendant school were not caught by the Bill of Rights, referred to section 3(a) as applying to: 29

acts done directly by one of the three branches of Government, or, arguably, to the acts of an agent of one of the three branches of Government where there is evidence of a close and direct relationship of agency.

While leaving the issue open, if correct, Goddard J's notion of "agency" envisages a broader scope for section 3(a), addressing itself to the realities of the myriad ways and forms in, and through, which modern government acts.

Under Her Honour's analysis it may well be open to hold that an SOE such as New Zealand Post falls within the notion of agency and is thus caught by section 3(a). After all, the Privy Council in New Zealand Maori Council v Attorney-General (the Broadcasting Assets case $)^{30}$ said of an SOE that while "structured so that it is separate from the Crown ... it remains very much the Crown's creature." Moreover, the Privy Council examined in some detail the involvement of the Crown in SOEs and concluded that "the Crown can exercise a

27 For example, in Innes $v$ Wong (No 2) (1996) 4 HRNZ 247, 248 (HC) Cartwright J implicitly defined the scope of s 3(a) as embracing the Crown or those for whose actions the Crown has direct responsibility. On this approach, the activities of Crown Health Enterprises were held to be caught by s 3(b) rather than by s 3(a) of the Bill of Rights.

28 M v Palmerston North Boys High School (1996) 3 HRNZ 515 (HC).

29 M v Palmerston North Boys High School above n 28, 532-533 (emphasis added).

30 New Zealand Maori Council v Attorney-General [1994] 1 NZLR 513, 520 (PC). 
substantial degree of indirect control over the manner in which [SOE] assets are employed." 31

\section{(d) Common law private law governed by the Bill of Rights}

Let us concentrate now on acts of the judicial branch.

At the outset it needs to be reaffirmed that "The Judges speak and act on behalf of the community."32 They have been entrusted with substantial power, backed up by the coercive authority of the state, to be exercised in the Sovereign's name and on our behalf. It is only proper then that judicial activity be subject to the same strictures as to processes and outputs as the other two branches of government. And this explains why our drafters explicitly included the judicial branch of the government of New Zealand in the section 3(a) limb of the Bill of Rights.

Turning to the case law, as regards the general point that the judiciary is bound to give effect to the Bill of Rights in relation to its output, the words of Cooke P in Baigent's case are apposite: ${ }^{33}$

Section 3 [of the Bill of Rights] also makes it clear that the Act applies to acts done by the

Courts. The Act is binding on us, and we would fail in our duty if we did not give an effective remedy to a person whose legislatively affirmed rights have been infringed.

The importance of this statement lies in its acknowledgement that it is not the presence of government before the court as one of the parties to the litigation (in Baigent's case the Attorney-General) which makes the Bill of Rights applicable; rather the Bill of Rights

31 M v Palmerston North Boys High School above n 28, 520. Moreover, while recent cases such as Te Heu Heu v Attorney-General [1998] NZAR 337 (HC) might be regarded by some as proof that an SOE is not to equated with the Crown, it is important to recall that Robertson J stated in that case (at 358):

There is no one rule or principle which can be applied to determine whether an entity should be regarded as an agent for the Crown. Rather, the answer will depend in each case on a full assessment of the words of the legislation in the context in which the issue arises, and the nature of the power being exercised by the body or the rights or privileges being sought.

Thus the decision that Landcorp was not part of the Crown for the purposes of the Crown's Treaty of Waitangi responsibilities does not govern the issue of whether SOEs for the very different purpose of the application of the Bill of Rights might not be thought of as Crown agents.

32 Broadcasting Corporation of New Zealand v Attorney-General [1982] 1 NZLR 120, 122 per Woodhouse P (CA). See also O'Connor v Police [1990-92] 1 NZBORR 259, 271 (HC) where Thomas J used the same words.

33 Baigent's Case above n 23, 676. 
applies because adjudication is an act of the judicial branch of government. In short, adjudication by a court or tribunal is a sufficient trigger to activate the Bill of Rights. ${ }^{34}$

Since a large part of the courts' adjudicatory jurisdiction covers private law disputes, ${ }^{35}$ through section 3 of the Bill of Rights public law reaches into the heart of private law requiring the latter to reshape itself in light of relevant public law standards. In this way, the Bill of Rights can be seen as public law's Trojan horse inside private law's city gates.

Lange $v$ Atkinson provides us with a recent example of this in the common law sphere. It will be recalled that former Prime Minister David Lange sued political scientist J B Atkinson and North $\mathcal{E}$ South magazine in relation to comments which he regarded as defamatory. The defendants submitted that the common law of qualified privilege ought to be extended to protect untrue statements made by the press to the general public so long as those statements were not made with malice. Both the High Court and Court of Appeal agreed with this submission. At both levels section 14 of the Bill of Rights (freedom of expression) was a significant feature in favour of the development of the law

34 To the contrary see the comments of Blanchard J in TVNZ Ltd $v$ Newsmonitor Services Ltd [1994] 2 NZLR 91, 96 (HC) who put the widest interpretation of s 3(a)'s reference to the judicial branch of government as requiring courts

to conduct themselves in accordance with the Bill of Rights in terms of their processes and procedures, but that this direction does not extend to the substance of their judgments and the orders which flow out of those judgments.

His honour opined that,

If it was intended that the Bill of Rights is directly to apply in relation to every question of statutory interpretation and every other substantive judicial decision Parliament might have been expected to so enact in plain terms.

With great respect this reasoning is illogical. His honour is plainly wrong in suggesting that the Bill of Rights does not directly apply in relation to every question of statutory interpretation - s 6 of the Bill of Rights, which requires the courts to give a meaning to enactments which is consistent with the Bill of Rights, and s 4 of the Bill of Rights which prevents the courts from invalidating or rendering ineffective any enactment, gives the lie to any contrary view. Next, no one suggests that there has been a "failure" by Parliament to bind every administrative act of government through the Bill of Rights, merely because all that is referred to in s 3(a) is the executive. If the phrase "the executive" is sufficient to cover all administrative acts, then surely the phrase "the judiciary" is sufficient to cover all judicial acts, including the common law. Moreover, it should be noted that Blanchard J's judgment was delivered 8 months prior to Baigent's case, and is inconsistent with Lange $v$ Atkinson discussed later.

35 A point noted by (and clearly troubling to) Holland J in Police v Geiringer [1990-92] 1 NZBORR 331, $343(\mathrm{HC})$ when discussing the proper reach of $\mathrm{s} 3$ of the Bill of Rights. 
in the manner advanced by the defendants. For our purposes the following statement of Elias J (as she then was) in the High Court is of great interest: ${ }^{36}$

In my view, the New Zealand Bill of Rights Act protections are to be given effect by the Court in applying the common law. ... The application of the Act to the common law seems to me to follow from the language of section 3 which refers to acts of the judicial branch of the Government of New Zealand ....

This view was seemingly approved by the joint judgment of Richardson P, Henry, Keith and Blanchard JJ in the Court of Appeal. ${ }^{37}$ (In its recent judgment, the Privy Council did not address this issue.)

The explicit reference to the judiciary in section 3(a), the inexorable logic of Cooke P's position in Baigent's case, and Elias J's view in Lange, makes the application of our Bill of Rights significantly different from the position in Canada. There, the common law is not as of right ${ }^{38}$ subject to the Charter unless one of the parties to the litigation is a governmental entity. This position has been adopted by the Supreme Court of Canada to reflect the language of the application provision of the Canadian Charter (s 32(1)). Section 32(1) makes reference only to the legislature and executive; unlike section 3(a) of our Bill of Rights there is no reference to the judiciary. ${ }^{39}$ On this basis (as well as on the basis of a wariness to subject all of the common law to Charter scrutiny) in Canada a rule of the common law may be applied in litigation between two private parties notwithstanding an apparent conflict between the rule and a substantive Charter right. ${ }^{40}$

36 Lange v Atkinson [1997] 2 NZLR 22, 32 (HC).

37 Lange v Atkinson [1998] 3 NZLR 424, 451 (judgment of Richardson P, Henry, Keith, Blanchard JJ) (CA).

38 See the discussion of Hill below n 41 as to the use of Charter values to inform the remoulding of the common law.

39 This point was taken by Elias J in Lange v Atkinson above n 36, 32.

40 The seminal case on this issue is Retail, Wholesale $\mathcal{E}$ Department Stores Union v Dolphin Delivery (1986) 33 DLR (4th) 176 (SCC) [Dolphin Delivery] where the union unsuccessfully attempted to challenge common law rules that regarded a secondary picket as amounting to the common law tort of inducing a breach of contract on the basis that the rules interfered with Charter rights of free expression. 
While the position under our Bill of Rights might differ from that in Canada, ${ }^{41}$ it is in line with the position in a number of overseas jurisdictions, such as the United States, ${ }^{42}$ South Africa ${ }^{43}$ and Ireland, ${ }^{44}$ and with the position which a number of commentators and

41 It is important, though, to note that in reality the Canadian position is not as different from our position as may at first appear, hence my use of "may" and of the phrase "as of right" in describing the position under s 32(1). For the Supreme Court has accepted that even in private litigation (that is litigation between two or more private persons) it is legitimate to use Charter values as a basis upon which to revisit and revise common law rules. (See Dolphin Delivery above $\mathrm{n} 40$ and Hill $v$ Church of Scientology (1995) 126 DLR (4th) 129 (SCC) (defamation action where both parties private).) Indeed, in light of this aspect of the Canadian jurisprudence, Elias J commented in Lange $v$ Atkinson that even if the common law was not directly caught by the Bill of Rights (which she did not accept):

The New Zealand Bill of Rights Act 1990 is important contemporary legislation which is directly relevant to the policies served by the common law of defamation. It is idle to suggest that the common law need not conform to the judgments in such legislation. They are authoritative as to where the convenience and welfare of society lies.

Lange v Atkinson above $\mathrm{n} 36,32$. Note also that the judgment of Richardson P, Henry, Keith and Blanchard JJ in the Court of Appeal above n 37, 450-451 draws attention to this significant difference between the New Zealand Bill of Rights and the Canadian Charter.

Finally, I note (and agree with) the comments of Hutcheon JA in Bank of British Columbia $v$ CBC (1995) 126 DLR (4th) 644, 672 (BCCA) to the effect that there is no meaningful distinction between the application of the Charter and the application of Charter values - either the Charter applies or it does not.

42 See Shelly $v$ Kraemar (1948) 334 US 1.

43 See s 8 of the Constitution of the Republic of South Africa 1996 (4 HRNZ 740-741). Note that under the so-called interim Constitution of 1993, a majority of the Constitutional Court of South Africa in Du Plessis v De Klerk (1996) 5 BCLR 658; (1996) 3 SA 850 (SACC) (a defamation case) essentially adopted the Canadian position. That position has been effectively reversed by s 8 of the 1996 Constitution.

44 See JW $v$ JW [1993] 2 IR 476 (IrSC) (common law rules related to dependent domicile inconsistent with equality between men and women) and see generally A S Butler "Constitutional Rights in Private Litigation: A Critique and Comparative Analysis" (1993) 22 Anglo-Amer L Rev 1 and A S Butler "Private Litigation and Constitutional Rights under sections 8 and 9 of the 1996 Constitution - Assistance from Ireland" (1999) 116 SALJ 77. 
judges expect to emerge under the recently enacted United Kingdom Human Rights Act $1998 .{ }^{45}$

In an article in the New Zealand Law Journal some years ago, I argued that the Bill of Rights applied to all common law litigation, but finished by agreeing with Paul Rishworth that due to the pervasive presence of statute in New Zealand and the regular updating of the common law by statute, it may well be that "there are very few instances of common law rules which could be impugned for inconsistency with the Bill of Rights". ${ }^{46}$ Thus, public law's Trojan horse may be thought not to have significant potential impact on private law. This would be a false view to adopt.

\section{(e) Statutory private law governed by the Bill of Rights}

First, the sphere of private law which is subjected to the Bill of Rights extends well beyond rules of the common law which regulate private relationships. Statute is subject to the Bill of Rights. To the extent that legislative regimes govern interpersonal relationships they must adhere to public law standards. Overseas, this has seen challenges to such aspects of private law governed by statute as limitation periods, ${ }^{47}$ rent control, ${ }^{48}$ evictions, anti-discrimination statutes ${ }^{49}$ and so on. In a New Zealand context it is not open to parties to litigation to seek to strike down a statutory provision which interferes with their rights and freedoms - section 4 of the Bill of Rights prevents this. ${ }^{50}$ Nonetheless, if there is no express or necessarily implied inconsistency between the statute and the Bill of Rights, the

45 See in particular s 6 of the Act which defines "public authority" (the application phrase) to include the courts, and the comments thereon by Lord Irvine of Lairg (the Lord Chancellor) 583 PD (HL) 783 (24 November 1997); W Wade "The United Kingdom's Bill of Rights" in The University of Cambridge Centre for Public Law Constitutional Reform in the United Kingdom: Practice and Principles (Hart Publishing, Oxford, 1998) 62-63. See, for a view contrary to that of Sir William Wade's, S Kentridge "The Incorporation of the European Convention on Human Rights" in the same volume 70 .

46 A S Butler "The New Zealand Bill of Rights and private common law litigation" [1991] NZLJ 261, 265.

47 See O'Brien v Keogh [1972] IR 144 (IrSC); O'Brien v Manufacturing Engineering Ltd [1973] IR 334 (IrSC); Moynihan v Greensmyth [1977] IR 55 (IrSC).

48 Blake v Attorney-General [1982] IR 117 (IrSC).

49 See Blainey v Ontario Hockey Association (1986) 26 DLR (4th) 728 (OntCA) and In re Art 26 of the Constitution and the Employment Equality Bill 1997 (1997) 4 BHRC 91 (IrSC).

50 However, since the Court of Appeal's judgment in Moonen v Film and Literature Board of Review (1999) 5 HRNZ 224 (CA) the possibility appears to exist for a party to obtain a declaration that a statute places an unjustified limitation on his/her rights contrary to s 5 of the Bill of Rights. For more on this possibility, see A S Butler "Judicial Indications of Inconsistency - A New Weapon in the Bill of Rights Armoury?" [2000] NZ L Rev 43. 
meaning most consistent with the Bill of Rights must be given (section 6 of the Bill of Rights). Thus, for example, section 14 of the Bill of Rights (freedom of expression) has been raised in at least two commercial cases between private parties: P C Direct $v$ Best Buy $L t d,{ }^{51}$ and Cosco (NZ) Ltd $v$ Port of Napier, ${ }^{52}$ and in proceedings under the Harassment Act 1997: Beadle $v$ Allen. ${ }^{53}$ Furthermore a recent law review article has persuasively argued that aspects of New Zealand copyright law may need revisiting in order to ensure a proper balance between property rights and free expression. ${ }^{54}$

Moreover, the Bill of Rights will be relevant at the parliamentary stages of any legislation which governs private relationships. Indeed, the extensive number of submissions contesting the exclusion of same-sex couples from the coverage of the De Facto Relationships (Property) Bill 1998 on the ground that it discriminated against gays and lesbians contrary to section 19(1) of the Bill of Rights serves to illustrate that even in such a paradigmatically private law field as family law, public law standards set a highly relevant benchmark.

\section{(f) Does the Bill of Rights require lacunae in private law to be plugged?}

Second, the courts have yet to determine whether gaps in private law, which leave a citizen without a remedy when another person interferes with a right or freedom contained in the Bill of Rights, represent "acts" of the judicial or legislative branches of government. If the courts do accept such a proposition then public law will bring about significant developments within the field of private law.

A concrete example may help understanding. New Zealand law is still slowly evolving a tort of privacy. ${ }^{55}$ At present, a private person who is subjected to intrusive video or other surveillance has no remedy in tort. One of the reasons for this is that the judges have failed to evolve the law in this direction. Is this lacuna a judicial act for the purposes

51 P C Direct $v$ Best Buy Ltd (1997) 7 TCLR 452, 462 (HC) where Elias J expressed her concern "not to cut across the rights to freedom of speech and to receive information protected by s 14 of the New Zealand Bill of Rights Act 1990" in the context of an application for an interlocutory injunction in an action under ss 8 and 9 of the Trademarks Act 1953.

52 Cosco (NZ) Ltd v Port of Napier (31 March 1999) unreported, High Court, Napier Registry, CP 7/99, 15-16.

53 Beadle v Allen (9 November 1999) unreported, High Court, Auckland Registry, AP42/98.

54 J Oliver "Copyright, Fair Dealing, and Freedom of Expression" (2000) 19 NZULR 89.

55 See generally J Burrows "Privacy" in S Todd (ed) The Law of Torts in New Zealand (2 ed, Brookers, Wellington, 1997) 955ff. 
section 3(a) ?6 $^{56}$ If it is, and assuming that video surveillance is a "search" for the purposes of section 21 of the Bill of Rights (right not to be subjected to unreasonable search or seizure), how might an aggrieved citizen take action? Presumably, the most satisfactory approach would be to assert the existence of a common law privacy cause of action in one's pleadings and use section 21 of the Bill of Rights as the basis for resisting any strike out application: would not a decision to grant the strike out application contravene Cooke P's warning in Baigent's case that "we would fail in our duty if we did not give an effective remedy to a person whose legislatively affirmed rights have been infringed"? ${ }^{57}$

In this regard, the Court of Appeal's judgment in Sharma v ANZ Banking Group ${ }^{58}$ takes on an added significance. In that case, the appellant sought to set aside a bankruptcy notice on the basis that in terms of section 19(1)(d) of the Insolvency Act 1967 he had a counterclaim against the respondent bank which exceeded the amount of the judgment debt which the bank had claimed against him. This counterclaim was said to arise, inter alia, from the highhanded and contemptuous manner in which the bailiffs had exercised a writ of sale on behalf of the bank, allegedly indiscriminately seizing household possessions, a considerable number of which may not have belonged to the appellant but rather to his wife. In dismissing the appeal on the pleadings, Cooke P for the Court made the following pregnant observation: ${ }^{59}$

It is perhaps not inconceivable - we say no more - that if the appellant and his wife were to consolidate their proceedings and jointly sue the bank and others on an allegation of unreasonable search and seizure within the meaning of the Bill of Rights (New Zealand Bill of Rights Act 1990, section 21) or infringement of their or their family's rights to privacy under the common law, some cause of action might be established.

56 For discussion of this issue in relation to the UK Human Rights Act 1998 see J Coppel and S Ekins "Privacy and press freedom under the European Convention" [1998] Sol J 130, 131; M Hunt "The 'Horizontal Effect' of the Human Rights Act" [1998] PL 423; I Leigh "Horizontal Rights, the Human Rights Act and Privacy: Lessons from the Commonwealth" (1999) 48 ICLQ 57; P Milmo "Human rights, privacy and the press" [1997] NLJ 1631.

57 This would seem to be the position in South Africa and Ireland. For South Africa see ss 8 and 9 of the 1996 Constitution above n 43. For Ireland see Kennedy $v$ Ireland [1987] IR 587 (IrHC) where a very substantial award of damages was made against the state for interference with the constitutional right to privacy (unlawful tapping of journalists' phones). The Court gave this remedy notwithstanding the absence of a common law or statutory cause of action, on the basis that a failure to do so would be a failure to vindicate the plaintiffs' constitutional rights. The case was cited by Hardie Boys J in Baigent's case above n 23, 702. For the use of the Constitution to plug lacunae in the law between private parties see Conway $v$ INTO [1991] 2 IR 305 (IrSC) (also referred to by Hardie Boys J in Baigent's case).

58 Sharma v ANZ Banking Group [1990-92] 3 NZBORR 183 (CA).

59 Sharma $v$ ANZ Banking Group above n 58, 190. 
Here is a clear suggestion that the Bill of Rights may well give rise to new causes of action per se, regardless of the identity of the parties to the litigation, and even in circumstances which might more traditionally be regarded as falling within the province of "private law".

\section{Section $3(\boldsymbol{b})$}

Let us direct our attention now to section 3(b) of the Bill of Rights. Recall that in terms of that subsection,

3 Application - This Bill of Rights applies only to acts done-

(b) By any person or body in the performance of any public function, power, or duty conferred or imposed on that person by or pursuant to law.

What is the intended scope of this provision? ${ }^{60}$

We have already noted that in a number of judgments section 3(b) has been regarded as bringing within the purview of the Bill of Rights acts of publicly-owned companies such as SOEs and related organisations. I have queried whether in fact it would not be more appropriate for such bodies to be regarded as part of the executive branch in terms of section 3(a) and hence bound in respect of all of their activities by the Bill of Rights. But assuming arguendo that the present jurisprudence remains in place, which acts are caught by section $3(\mathrm{~b}){ }^{61}$

\section{(a) Trading activities of SOEs and other Crown entities}

This has proven to be a vexing question. First, it has been suggested that where an SOE engages in trading activities in a manner similar to comparable private businesses, section 3(b) does not apply because the impugned function, power or duty lacks a "public" dimension. The argument is simply that powers which ordinary persons and legal entities enjoy cannot be "public" powers; and such powers cannot transmute into public ones just because the actor has a public, as opposed to private, character or identity. If accepted, such a view would exempt the exercise of contractual and property rights by SOEs from Bill of Rights review. The authorities on this issue are divided.

60 In addition to the cases discussed below, I note that the Speaker of the House of Representatives is caught by s 3(b) when controlling access to Parliament grounds: Police v Beggs [1999] 3 NZLR 615, 626 (HC, Full Ct). This case does not impact upon the theme of this paper that public law applies to much private activity and is not discussed further.

61 See also A Shaw "Drug Testing in the Workplace and the Bill of Rights" [1995] NZ L Rev 22, 59-61. 
In TVNZ Ltd $v$ Newsmonitor Services Ltd, ${ }^{62}$ Blanchard J opined that TVNZ's trading activities did not fall within the ambit of section 3(b). While, with respect, His Honour's reasoning is not fulsome (reflecting the fact that the point was not fully argued) it seems clear that the reasoning for this holding was that there was nothing about the way in which TVNZ traded which distinguished it from any private business enterprise. Accordingly, there was nothing sufficiently special about its trading activities to indicate that those activities were done in the performance of a public function, power or duty. In so concluding, Blanchard J relied on the then recent judgment of the Court of Appeal in Auckland Electric Power Board v ECNZ, which had held that ECNZ's contracts with its suppliers were private trading activities and so were not susceptible to judicial review. However, subsequent to Blanchard J's judgment the Privy Council overruled the Court of Appeal's reasoning on this point, holding that ECNZ's status as a public body was sufficient to render its contractual activities reviewable in principle (Mercury Energy $v$ ECNZ). ${ }^{63}$ For this reason alone, it is submitted that Newsmonitor is not good law.

Indeed, Blanchard J's approach was criticised by Williams J in Lawson $v$ Housing New Zealand. ${ }^{64}$ In that case the plaintiff challenged Housing New Zealand's (HNZ) decision to move to a market rent policy on the ground, inter alia, that it was an interference with her right to life (section 8 of the Bill of Rights). It was submitted for HNZ that the Bill of Rights did not apply. ${ }^{65}$ More specifically, section 3(b) did not apply because a rent increase was "a private function carried out by a landlord" not one done pursuant to statute. ${ }^{66}$ Williams $\mathrm{J}$ rejected this argument correctly holding that "the act done, the increasing of rent, does not need to be public provided it is done in the performance of a public function power or duty." 67 In other words, the mechanism through which a public function, power or duty is implemented is not determinative of the application of section $3(b)$; what is determinative is that that mechanism (even if it is one also resorted to by a non-public person or body) is being used so as to carry out a public function, power or duty conferred or imposed by law.

62 TVNZ Ltd v Newsmonitor Services Ltd [1994] 2 NZLR 91 (HC).

63 The Court of Appeal and Privy Council judgments are discussed in more detail in the Judicial Review section below.

64 Lawson v Housing New Zealand (1996) 3 HRNZ 285 (HC).

65 There does not appear to have been any discussion as to whether HNZ fell within s 3(a) of the Bill of Rights.

66 Lawson $v$ Housing New Zealand above n 64, 328.

67 Lawson $v$ Housing New Zealand above n 64, 329. 
This must be correct. It would not be right for the implementation of public functions to be exempt from Bill of Rights review through the simple device of contract. This is more so the case where the contract is standard term or long term. ${ }^{68}$ (Where Williams J's analysis is in turn deficient is that he fails to explain what public function, power or duty HNZ was giving effect to when it determined to increase its tenants' rents. Without this analysis, his decision that HNZ's acts "on balance" fell within section 3(b) is with respect suspect.)

In the earlier case of Federated Farmers, McGechan J had also rejected the argument that section 3(b) did not apply to contracts entered into by New Zealand Post and its customers. His Honour held that mail handling was a public function carried out in the public interest by an entity which, while technically a separate entity, was wholly owned and ultimately controlled by the Crown. Moreover, the genesis of its functions lay in an assembly of statutes including the SOE Act itself and the Postal Services Act 1987. The clear import of McGechan J's approach is that though New Zealand Post may interact with individual users of its services on a contractual basis, that contractual relationship with individuals does not detract from the statutory backdrop nor from the public nature of the function which it performs.

\section{(b) Private persons/entities and section 3(b)}

(i) Wholly private conduct outside section 3(b) ...

The Courts have emphasised a number of times that the Bill of Rights does not apply to all private activity - it only applies to those acts of private citizens or private entities which fall within the wording of section 3(b). The result is that "[w]holly private conduct is left to be controlled by the general law of the land." 69

(ii) $\quad .$. but private identity of actor does not mean conduct outside section 3(b)

On the other hand, an important feature of Williams J's judgment in Lawson was His Honour's clear affirmation that for section 3(b) to be triggered it was not decisive that the particular body the acts of which are impugned "is essentially private in nature". ${ }^{70}$ What is determinative is whether, notwithstanding the entity's private character, it can be said to

68 See in this regard the powerful obiter comments of Henchy J in McCord v Electricity Supply Board [1980] ILRM 153, 161-162 (IrSC) criticising aspects of the ESB's standard term electricity supply contract by reference to public law values (including constitutional rights). His Honour likened the standard form contracts of a monopoly supplier of a vital public utility to a set of bylaws. Note that the ESB is, essentially, the Irish equivalent of an SOE.

$69 R v N$ above $n 24,718$ (CA). Of course, in its turn the general law of the land will be subject to the Bill of Rights through s 3(a).

70 Lawson v Housing New Zealand above n 64, 329. 
be performing a public function, power or duty. Close attention will need to be paid, therefore, to the exact circumstances of the case and the constellation of statutory and common law rules which establish the framework within which the particular act or acts have occurred.

(iii) Private persons and criminal investigations

Thus, for example, the acts of an employee in searching, seizing and handing over to the police incriminating documents owned by his employer were not caught by section 3(b), for the period that the initiative was being taken by the employee. Once, however, the employee started taking directions from the investigating police officers, and hence acting in effect as their agent, section $3(b)$ was engaged. ${ }^{71}$

Equally, whether acts of private citizens in arrest situations will be caught by the Bill of Rights depends on some quite fine shading. In $R v N$ the Court of Appeal stressed that for section 3(b) to be engaged the impugned acts must fall strictly within the words of the subsection and be classifiable as the exercise of a public "power" or "function" or "duty".72 Thus, a purported citizen's arrest will in general fall outside the reach of section 3(b) because there is no general power of citizen's arrest, only a broad range of civil and criminal immunities in those situations in which a citizen's arrest is effected. ${ }^{73}$ But in those limited circumstances in which specific powers are given to a private citizen to effect an arrest (Crimes Act 1961, sections 315(2) and 317 - citizens called upon by a constable to lend assistance) then the Bill of Rights applies. ${ }^{74}$ The upshot was that in N's case even if the respondent's detention by store staff on suspicion of theft had been an arbitrary one, the guarantees in section 22 of the Bill of Rights would not have been relevant, because section 3(b) was not triggered - the arrest was wholly private conduct, not the exercise of a public power.

\section{(iv) Contract prisons}

The Penal Institutions Act 1954 (as amended) permits the use of private prisons to house inmates. It is of great interest in terms of our analysis of section 3(b) of the Bill of Rights, that section 41E of the 1954 Act explicitly provides that in respect of contract penal institutions, the Bill of Rights applies. Here we have Parliament underscoring the point that public identity/ownership is not the test under section 3(b), but rather public functionality is.

$71 R v H$ [1994] 2 NZLR 143, 147 (CA).

$72 R v \mathrm{~N}$ above $\mathrm{n} 24$.

73 See Part II of the Crimes Act 1961.

$74 \quad R v \mathrm{~N}$ above $\mathrm{n} 23,719$. 
(v) Private entities acting under licence

The judgment of Cooke P in TV3 Network Ltd $v$ Eveready New Zealand Ltd is also significant to the application of the Bill of Rights to private entities. ${ }^{75}$ There, it was argued that TV3, a private broadcaster, could be forced to publish corrective material upon the showing of actionable defamation. Cooke P opined that section 14 of the Bill of Rights (freedom of expression, in particular the right to impart information) might well support a jurisdiction to compel retraction or rectification. If it were, would the Bill of Rights apply against TV3? On that issue, Cooke P stated:

By section 3(b) the Bill of Rights applies to acts done by any person or body in the performance of any public function, power, or duty conferred or imposed on the person or body by or pursuant to law. In this case it is admitted that [TV3] is a duly licensed television broadcaster under the Broadcasting Act 1989. Certain responsibilities, including some relating to balance in controversial issues of public importance, fall on it under section 4 of that Act.

His Honour concluded that the Bill of Rights might well support an order that corrective information be broadcast by TV3.

Though somewhat oblique, Cooke P's judgment in the TV3 case seems to indicate that notwithstanding TV3's private ownership, its exercise of broadcasting functions pursuant to licence and its subjection to duties under section 4 of the Broadcasting Act made it subject to the Bill of Rights in relation to its broadcasting activities (that is those acts related to the performance of the power or function authorised by the licence). ${ }^{76}$

Radich and Best caution that, "It is important to read these comments within the context of the case. The mere fact that a television network or other body is licensed by statute would not be sufficient to render it subject to the BORA."77 I agree. Just because I hold a driver's licence does not mean I perform a public function when I take a spin in my car. However, in many cases licensing of private operators will reflect the existence of an underlying public function, power or duty. Thus, licensing, though not determinative, will provide a useful indicium as to whether the Bill of Rights applies. This could well have ramifications for a host of private utilities entities which operate under statutory licensing regimes, such as telephone services providers, power companies and so on. Perhaps also banks might be caught if regarded as performing a public function?

(vi) Education

75 TV3 Network Ltd v Eveready New Zealand Ltd [1993] 3 NZLR 435 (CA).

76 See also Radich and Best, above n 15, 252.

77 Radich and Best, above n 15, 252. 
The education sector is another field in which the application of public law values through the Bill of Rights is likely to be situation-specific. This is due to the mixed education delivery systems in place, and the diverse range of facilities offered by various educational institutions.

In his interesting paper, "Biculturalism, Multiculturalism, the Bill of Rights and the School Curriculum"78 Paul Rishworth has, correctly in my view, concluded that state school (and integrated school) teachers, as well as state and integrated school boards of trustees are subject to the Bill of Rights through section 3(b). However, Rishworth also concludes that teachers and managers of private schools, even those registered and inspected in terms of section 35A of the Education Act 1989, do not exercise a public function pursuant to law in terms of section 3(b): "The state certainly inspects and registers them, but this does not in my view convert them to state institutions". ${ }^{79}$

With respect, this view does not bear scrutiny - suggesting that an entity in order to be caught by section $3(\mathrm{~b})$ has to amount to a state institution completely misses the point of the sub-section. That provision is premised on the notion that you can preserve your formally private identity, yet in respect of all or many or a few of your activities, exercise public functions, powers or duties. Thus, the enquiry is not whether you are in substance a state institution, but whether you perform public functions, powers, and so on. Moreover, Rishworth's approach falls into the trap of co-equating "public" and "state". As emphasised above, the two may have significant common overlapping areas but they are not the same, and as a general proposition it can be asserted that the notion of "public" exceeds the boundaries of the notion of the "state". In conclusion, then, Rishworth's view that private schools may not be converted into "state institutions" through the inspection and registration schemes may well be correct, but does not answer any question relevant to a section 3(b) analysis.

Moreover, the registration and inspection scheme, seen in the context of a compulsory education scheme, must make private schools at least as "public" as a private broadcaster licenced under the Broadcasting Act 1989. In light of the observations of Cooke P in TV3 it is more than arguable that section 3(b) catches private schools.

Finally, it is hard to believe that the core nature of a service is altered by the fact of its delivery through the private, or the public, sector. ${ }^{80}$ If education provided by the state

78 P Rishworth "Biculturalism, Multiculturalism, the Bill of Rights and the School Curriculum" in Legal Research Foundation Education and the Law in New Zealand (Legal Research Foundation, Auckland, 1993) ch 2, 18-20 ["The Bill of Rights and the School Curriculum"].

79 "The Bill of Rights and the School Curriculum" above n 78, 19.

80 This general point is reinforced, in my view, by the treatment of contract penal institutions in the Penal Institutions Act 1954, s 41E. As discussed in "The Bill of Rights and the School Curriculum" 
school sector is a public function exercised pursuant to the Education Act 1989, what is so different about the education provided through private schools registered and inspected under the same Act so as to render it not-public? This substantive issue is not addressed by Rishworth. ${ }^{81}$

Again let me reiterate a point made at the outset of the article - even if private registered schools are caught by section $3(b)$ of the Bill of Rights that does not mean that their admittedly special character would not be taken account of in determining the substantive impact of the Bill of Rights on their activities. Section 3 is only a threshold question. If the Bill of Rights applies it could well be argued, for example, that while a state school could not engage in "partisan" religious teaching, a private catholic school could. But equally if it is improper for a state school to subject pupils to unreasonable searches contrary to section 21 of the Bill of Rights, ${ }^{82}$ it is hard to see why pupils at private registered schools receiving substantial state funding should not enjoy the same protections.

As yet there is little by way of concrete case law on the application of section 3(b) to the education sector. However, in Mv Palmerston North Boys High School Goddard J had to consider whether a decision to expel a pupil of Palmerston North Boys High School (PNBHS) (admittedly a state school) from the boarding school (potentially leaving him as a day pupil) was amenable to Bill of Rights scrutiny. ${ }^{83}$ Her Honour concluded that the specific relationship between PNBHS and the plaintiffs in relation to boarding was "a private commercial arrangement", and not one which could be regarded as the exercise of a public function or power conferred by or pursuant to law. ${ }^{84}$ Whether this case is rightly decided may be open to doubt - in reaching her conclusion, Goddard J relied on the decision of Blanchard J in the Newsmonitor case which I have criticised earlier. Moreover Her Honour failed to recognise that in many instances (for example rural state high schools) a pupil's attendance at school necessarily requires the provision of accommodation by the school thus boarding services could well be regarded as a core function of state schools. That

above $\mathrm{n}$ 78, 19 such prisons have been made explicitly subject to the Bill of Rights, notwithstanding their private ownership/identity.

81 However, identity can have significance in certain cases - no one is suggesting, for example, that a parent who home teaches as permitted by the Education Act is exercising a public function within the meaning of s $3(\mathrm{~b})$ of the Bill of Rights, even though that home teaching is the substitute for state-provided/approved education.

82 See the Report of the Commissioner for Children Re Strip Search at Hastings Boys High School [19901992] 1 NZBORR 480, 495, 497.

83 Mv Palmerston North Boys High School above n 28.

84 Mv Palmerston North Boys High School above n 28, 533. 
said, the obvious difficulty of the issue, apparent from Goddard J's judgment, underscores the complexity of the issues raised by section $3(\mathrm{~b})$ and the substantial measure of uncertainty as to where public law ends and private law begins.

(vii) Is government control a prerequisite to triggering section 3(b)?

In Alexander $v$ Police a question arose as to whether the Bill of Rights applied to certain acts of ambulance officers of the Wellington Free Ambulance Service Inc done at the scene of a traffic accident. ${ }^{85}$ The Court of Appeal noted that the organisation is "independent" and could "not be seen as an arm of central or local Government."86 Furthermore, "notwithstanding its public role", nor the fact that it received funding from a variety of sources including the government's Health Funding Authority (HFA), the Court concluded (citing two Canadian authorities) that "in no way can it be said to be acting as an agent of or otherwise under governmental control or implementing a Government policy or programme". 87

With respect, this reasoning does not fit well with the terms of section 3 , nor with the case law discussed above (none of which, it should be noted, was referred to by the Court). First, section 3 is not tied, on its terms, to the implementation of governmental policies or programmes; rather it captures public functions, duties and powers. "Public" and "governmental" are not synonymous; the former is clearly broader than the latter. Second, section 3(b) nowhere mentions concepts of "control", "agency", "independence", "arm of ... government" or the like; it refers to public functions, duties and powers. The importation of concepts not found in section 3(b) in order to restrict its application is improper. And to many people, the provision of ambulance services is the performance of a public function - that is after all why the HFA pays for it. Third, in light of the very different wording of the Canadian Charter (noted by both Elias J and the Court of Appeal in Lange v Atkinson) ${ }^{88}$ it was improper to use Canadian case law to read down the scope of our section 3(b). Fourth, it could be equally said of TV3 that it is independent of government, is not an agent of government and does not implement governmental programmes or policies in its broadcast activities, yet the Court of Appeal had hinted that section 3(b) probably applied to its operations. How does Alexander square with this?

85 Alexander v Police (1998) 4 HRNZ 632 (CA).

86 Alexander $v$ Police above $\mathrm{n} 85,637$.

87 Alexander v Police above n 85, 637.

88 Discussed above $n$ 36-39. 
In conclusion, it is suggested that Alexander should not be regarded as correctly stating the law of New Zealand on section 3(b) coverage. In an appropriate case it will require reassessment so as to ensure that the true purpose and language of section 3(b) is given effect to and that the confining notions of "control", "agency" and "implementation" are abandoned.

\section{JUDICIAL REVIEW ${ }^{89}$}

\section{A General Observations}

At the outset it is important to re-iterate the point that those cases which the courts refuse to allow to proceed by way of judicial review do not, by that reason alone, fall outside of the "public law" classification. As noted in the introduction many traditional areas of private law such as torts, contract and equity now have significant fields in which public law considerations play an explicit role in determining liability. A holding that a decision is not susceptible to judicial review only need mean/means that that procedure is inappropriate to the circumstances of the allegations made, not that the case is not a public law one. In the same way as many Bill of Rights issues are raised without reliance on the judicial review procedure (for example section 344A Crimes Act applications; exclusion of evidence for breach of criminal procedure rights; suits for Baigent damages; and so on) so too many other public law issues can emerge outside of the judicial review arena. Nonetheless, the area of judicial review is a useful barometer of those issues which the courts feel are properly examined by reference to public law principles. And as we shall see there have been important developments, pushing the boundaries between public and private.

A second important point to affirm is that judicial review is available both under statute (Judicature Amendment Act 1972 (JAA) and Part VII High Court Rules) and at common law. Hence, there need be no fixation on the existence of a statutory power - as we shall see judicial review at common law has evolved to the position where the exercise of public power will be the proper subject matter of public law review even absent a statutory power.

Next, in New Zealand, it might be thought that the well-known and often artificial and sterile English judicial review debate over "public" and "private" is quite irrelevant. ${ }^{90}$

89 See generally for a thoroughgoing treatment of the law and principles of judicial review in New Zealand, G D S Taylor Judicial Review A New Zealand Perspective (Butterworths, Wellington, 1991) (with supplement 1997).

90 The seminal case is O'Reilly $v$ Mackman [1983] 2 AC 237 (HL). See for example P P Craig Administrative Law (3 ed, Sweet \& Maxwell, London, 1994) ch 15. 
After all the generous definitions of "statutory power" and "statutory power of decision" in 
the JAA ensure that even decisions taken contrary to the rules of an incorporated organisation are properly the subject matter of a review application under the Act. ${ }^{91}$

Nonetheless the public/private distinction is still of significance. Whether the case is properly analysed as a public law one or an essentially private law one may well affect the type and intensity of review applied. Accordingly, this requires public lawyers and judges alike to determine criteria for establishing that the particular case is a public law one, with the consequences that may have for the content of the standards which will apply and the intensity of review which will be exacted. In other words, there should be a focus on substance not form: just because the JAA applies does not mean that the case is a public law one and that public law type of review and intensity of review should apply.

This may appear straightforward enough, but there are complications. First, public lawyers have rediscovered the elemental truth that "'public power' and 'governmental power' are not co-extensive": ${ }^{92}$ public law is as much about the abuse of power which affects the public interest regardless of the identity of the person or body who has committed the impugned acts as it is about the regulation of the activities of public institutions and bodies in the performance of their activities. In other words, determining whether a case is a public law one for the purposes of judicial review cannot be answered by the expedient of the identity of the actor. Second, even if a case is a public law one the intensity of review is variable. We should not be surprised therefore if on occasion the intensity of review to which a public body is subjected is less than that which prevails in a private law context. ${ }^{93}$

\section{B The Importance of the Nature of the Function}

\section{The Datafin case}

That identity is not the determinative factor in deciding whether a case is a public law one or not was graphically illustrated by the important English Court of Appeal judgment in ex parte Datafin. ${ }^{94}$ There the applicant sought judicial review of a determination of the

91 See Peters $v$ Collinge [1993] 2 NZLR 554 (HC) and Naden v Judicial Committee of Auckland Racing Club (Inc) [1995] 1 NZLR 307 (CA). If we look at the JAA, we can see that its wording is ample enough to catch the conduct of companies, incorporated and unincorporated bodies and so on (see s 3 definition of "person"). Moreover, while that "person" must exercise or purport to exercise a statutory power before the JAA applies, "statutory power" has also a very broad application, including any power conferred upon a "person" by legislation or under the constitution, rules or bylaws of a body corporate.

92 D Mullan "Administrative Law at the Margins" in M Taggart (ed) The Province of Administrative Law (Hart Publishing, Oxford, 1997) 154.

93 See to similar effect, Mullan, above n 92, 153.

94 Ex parte Datafin [1987] 1 QB 815 (Eng CA). 
Panel on Take-Overs and Mergers. The Panel was an unincorporated association without legal personality made up of some dozen members appointed by and representing the clearing banks, investment trust companies, insurers, the stock exchanges, pension funds and so on. It promulgated a code of conduct (the City Code on Take-overs and Mergers) intended to govern mergers and acquisitions; investigated and reported upon alleged breaches of the Code; and applied (or threatened to apply) indirect sanctions, such as public censure, referrals to private and public regulatory agencies and so on. All of this was done "without visible means of legal support", but evidence demonstrated that the sanctions were "no less effective because they are applied indirectly and lack a legally enforceable base." 95 Hence, although the Panel lacked "any authority de jure" it exercised "immense power de facto." 96 The issue was whether the Panel was the proper subject of public law judicial review. In holding that it was, the Court noted that:

(1) the state, in framing a scheme for the control of takeovers and mergers, had decided to use the Panel as the central regulatory body and erect around it a periphery of statutory powers and penalties dependent on decisions made by the Panel;

(2) the Panel operated wholly in the public domain;

(3) the Panel's "jurisdiction" extended to all acquisitions and mergers and affected all persons, whether they were represented on the Panel or not;

(4) the Panel "has a giant's strength";

(5) most equivalent institutions overseas were creatures of statute;

(6) control by established forms of private law such as actionable combinations in restraint of trade and so on would not be in the least effective.

As to underlying rationale, Sir John Donaldson MR opined that the real issue was whether the Panel in exercising such extensive de facto authority "is above the law". 97 Moreover, recalling the statutory scheme built around the Panel, His Lordship emphasised that in determining the jurisdictional issue courts must "recognise the realities of executive power" and must not allow "their vision to be clouded by the subtlety and sometimes complexity of the way in which it can be exerted." 98 In rejecting the submission of counsel for the Panel that it was not subject to review because the source of any authority it had

95 Ex parte Datafin above n 94, 824 and 826.

96 Ex parte Datafin above $\mathrm{n} 94,826$.

97 Ex parte Datafin above $\mathrm{n} 94,827$.

98 Ex parte Datafin above n 94, 839. 
was not to be found in statute or prerogative, Lloyd LJ (as he then was) emphasised that "it is not just the source of the power that matters, but also the nature of the duty." 99

It is important to emphasise however that in Datafin, having decided the jurisdictional issue against the Panel, the Court of Appeal proceeded to declaim any desire to interfere in much of the Panel's work. The Court expressed a reluctance to quash an interpretative decision of the Panel, to question the vires of promulgated rules, and so on. Indeed, in the later case of $R v$ Panel on Take-overs and Mergers, ex parte Guinness plc, ${ }^{100}$ the Court of Appeal rejected a claim that the Panel's refusal to adjourn a hearing into the activities of Guinness plc was unlawful, even though the Panel's investigations could have been pursued more thoroughly. While the decision not to adjourn was reviewable in principle, some latitude should be shown to the Panel's assessment of the relevant circumstances. This outcome reinforces the general point made previously that the threshold issue of determining susceptibility to public law does not dictate the intensity of review.

\section{Datafin's Progeny in England}

In subsequent cases in England and Wales plaintiffs have sought to use Datafin as the basis upon which to claim review of formally private institutions. Many of these have been unsuccessful. ${ }^{101}$ Thus, in $R v$ Disciplinary Committee of the Jockey Club, ex parte Aga Khan, ${ }^{102}$ the Court of Appeal held that the decision of the Jockey Club's Disciplinary Committee in relation to the disqualification of the applicant's horse was not susceptible to judicial review. This was so even though it was acknowledged that the Club - a private organisation - regulated a national activity and an activity, moreover, which would be in all probability the subject of governmental regulation were it not for the existence of the Club. In reaching its conclusion, the Court emphasised that the Club was not in its origin, constitution, membership or history a public body and that its powers were not governmental. Similarly in $R v$ Football Association, ex parte Football League Ltd, ${ }^{103}$ it was held that the Football Association (FA) was not subject to review à la Datafin. Its monopolistic powers in relation to the organisation of soccer were not sustained in any way by a state agency; there was no real governmental interest in its functions; and there

99 Ex parte Datafin above n 94, 848. See also His Lordship's comments 846-847.

$100 R v$ Panel on Take-overs and Mergers, ex parte Guinness plc [1990] 1 QB 146 (Eng CA).

101 In addition to the cases mentioned in the text see also $R v$ Lloyd's of London, ex parte Briggs [1993] COD 66. For a successful invocation of Datafin, see $R v$ Advertising Standards Authority, ex parte The Insurance Services plc [1990] COD 42.

$102 R v$ Disciplinary Committee of the Jockey Club, ex parte Aga Khan [1993] 2 All ER 853 (Eng CA).

$103 R v$ Football Association, ex parte Football League Ltd [1993] 2 All ER 833 (Eng HC). 
was no evidence that absent the FA the state would feel a duty to establish a public body in its stead.

One of the primary reasons for the reluctance to apply Datafin too readily is the awareness that while many private regulatory bodies do exercise power, indeed considerable power, over their area of operation such power does not necessarily equate to public power. Hoffmann LJ (as he then was) expressed the point in Aga Khan as follows: ${ }^{104}$

But the mere fact of power, even over a substantial area of economic activity, is not enough. ...

Private power may affect the public interest and the livelihoods of many individuals. But that does not subject it to the rules of public law. If control is needed it must be found in the law of contract, the doctrine of restraint of trade, [statute] and all the other instruments available for curbing the excesses of private power.

\section{The New Zealand approach: Electoral Commission v Cameron}

In New Zealand, a similar focus on function rather than character or identity was apparent in Electoral Commission $v$ Cameron. ${ }^{105}$ There, the Court of Appeal had to determine whether a ruling of the Advertising Standards Complaints Board was subject to judicial review. The Advertising Standards Authority Inc, a body corporate, had established under its rules the Complaints Board as an unincorporated body. The purpose of the Board was to adjudicate upon complaints that advertisements prepared or published by member organisations breached the Advertising Codes of Practice which had been adopted by the Society. In the instant case, the Board had found that advertisements published on behalf of the Electoral Commission breached the Codes of Practice. The Commission disputed this finding and sought to review the Board's decision.

The Court of Appeal speaking through Gault J readily concluded that section 4 of the JAA was triggered: the Board (a "person" for the purposes of section 3 JAA) was established under rules of an incorporated body (that is had a "statutory power" in terms of section 3 JAA). Thus, the Court did not need to rely on its common law jurisdiction to subject the Board to review as the English Court in Datafin had had to do.

But what type of review should the Board be subject to? Gault J - in terms redolent of Datafin - emphasised the fact that "whether by contract or by industry practice, the Board exercises a regulatory function by which it determines what advertising is or is not

$104 R v$ Disciplinary Committee of the Jockey Club, ex parte Aga Khan above n 102, 875.

105 Electoral Commission v Cameron [1997] 2 NZLR 421 (CA). 
communicated to the public by substantially the whole of the media throughout the country". ${ }^{106}$ Later, His Honour remarked:107

The board in carrying out its public regulatory role, though in accordance with powers conferred ... by a private organisation, must be regarded as exercising public power. That will be reviewable on public law principles.

Indeed, earlier he had noted that it would have been unfortunate if judicial review of the Board were not available, in light of the fact that non-member broadcasting organisations were subject to the jurisdiction of the Broadcasting Standards Authority established by statute - the jurisdiction of which was undoubtedly subject to judicial review.

Having determined the threshold application of the JAA, Gault J cautioned that, 108

Finding that decisions of the board are amenable to review still leaves for consideration the grounds upon which review may be granted. Decisions of unincorporated bodies exercising public regulatory functions may not easily fall for examination on conventional grounds of illegality, irrationality and procedural impropriety. In appropriate cases a more flexible approach may be called for.

His Honour went on to hold that a set of standards could be exacted of the Board different from that applicable to other bodies subject to public law review. His Honour indicated a greater willingness to intervene on reasonableness grounds (by application of a standard lower than the Wednesbury test) and on grounds of encroachment upon statutory functions or powers conferred on public authorities. ${ }^{109}$

\section{The Importance of the Actor's Public Character}

Having established that public character or identity is not the sole determinant by reference to which amenability to public law judicial review is decided, it seems important to affirm that in other cases that character or identity will be crucial to determining amenability to judicial review.

In particular, the public character of the actor whose acts are sought to be impugned is highly relevant where the impugned act is non-public in nature, invariably relating to contracts entered into by the public body. In Webster $v$ Auckland Harbour Board, ${ }^{110}$ the

106 Electoral Commission v Cameron above n 105, 424.

107 Electoral Commission v Cameron above n 105, 433 (emphasis added).

108 Electoral Commission v Cameron above n 105, 430.

109 Electoral Commission v Cameron above $\mathrm{n} 105$.

110 Webster $v$ Auckland Harbour Board [1983] NZLR 646 (CA). 
applicants sought to judicially review (under the JAA) the Auckland Harbour Board's (AHB) decisions (a) to withdraw an offer to renew a foreshore licence and (b) to require removal of a boatshed and launching ramp constructed by the licensees. The AHB submitted as a preliminary matter of law that judicial review did not extend to the decisions it had made as there was no exercise of statutory powers within the meaning of the JAA. It submitted that its decisions amounted to the exercise of contractual and/or property rights which it enjoyed and could exercise on the same unfettered basis as all natural and legal persons. The Court of Appeal disagreed. In their joint judgment Cooke and Jeffries JJ emphasised that "even when exercising contractual powers a public authority is not in exactly the same position as a private citizen." Their Honours continued: ${ }^{111}$

Undoubtedly a public body which has, as here, lawfully entered into a contract is bound by it and has the same powers under it as any other contracting party. But in exercising the contractual powers it may also be restricted by its public law responsibilities. The result may be that a decision taken by the public body cannot be treated as purely in the realm of contract; it may be at the same time a decision governed to some extent by statute.

While some later cases had suggested that Webster was a tentative statement of law, 112 its reasoning is reflected in the Privy Council's decision in Mercury Energy $v$ ECNZ. ${ }^{113}$ There, the Court of Appeal had rejected the proposition that ECNZ's decision to terminate an electricity supply contract with Mercury was susceptible to judicial review. The Court reasoned that a supply contract was not a public act which was susceptible to judicial review. ${ }^{114}$ But the Privy Council took a different approach, establishing that judicial review was, in principle, available against a contractual act of an SOE. Said Lord Templeman for the Board: ${ }^{115}$

A state-owned enterprise is a public body; its shares are held by ministers who are responsible to the House of Representatives and accountable to the electorate. The Corporation carries on its business in the interests of the public. Decisions made in the public interest by the Corporation, a body established by statute, may adversely affect the rights and liabilities of private individuals without affording them any redress. Their Lordships take the view that in these circumstances the decisions of the Corporation are in principle amenable to judicial

111 Webster $v$ Auckland Harbour Board above n 110, 650.

112 See NZ Stock Exchange v Listed Companies Assn Inc [1984] 1 NZLR 699 (CA).

113 Mercury Energy v ECNZ [1994] 2 NZLR 385 (PC).

114 Mercury Energy v ECNZ [1994] 1 NZLR 551 (CA).

115 Mercury Energy v ECNZ above n 113, 388. 
review both under the Act of 1972 [that is the Judicature Amendment Act 1972] as amended and under the common law.

His Lordship continued by referring to judicial review as being "a judicial invention to secure that decisions are made by ... a public body according to law even if the decision does not otherwise involve an actionable wrong."116 Thus, it was ECNZ's public body status which made its contracts susceptible to review.

However, while it cast a wide jurisdictional net, the Privy Council's decision should excite little concern among SOEs. ${ }^{117}$ This is because the grounds of review of an SOE's contracts are narrow. Lord Templeman held that to be successful, unreasonableness in the Wednesbury sense would have to be demonstrated by the aggrieved party and that it would be unlikely that "a decision by a state-owned enterprise to enter into or determine a commercial contract to supply goods or services will ever be the subject of judicial review in the absence of fraud, corruption or bad faith."118 This narrow range of review was justified, in his Lordship's opinion, because of the availability of other mechanisms, judicial and non-judicial, to appropriately control the exercise of contracting powers. ${ }^{119}$

On one view, the Privy Council's approach in Mercury is a case of giving with the one hand and taking with the other. Indeed, Mai Chen has questioned whether the Privy Council decision "is really different in effect from that of the Court of Appeal". ${ }^{120}$ Radich

116 Mercury Energy v ECNZ above n 113, 388.

117 See M Chen "Accountability of SOEs and Crown-owned Companies: Judicial Review, the New Zealand Bill of Rights Act and the Impact of MMP" [1994] NZLJ 296, 298 and Taggart, below n 118.

118 This narrow set of grounds has been criticised in M Taggart "Corporatising, Contracting and the Courts" [1994] Public Law 351.

119 To these reasons might be added those expressed in earlier New Zealand cases emphasising the competitive disadvantage which SOEs and other public bodies would operate under if judicial review of their contractual arrangements was available. As Blanchard J put it in NZ Private Hospitals Assn Auckland Branch Inc v Northern Region Health Authority (7 December 1994) unreported, High Court, Auckland Registry, CP440/94, 42, it would be

[I]ntolerable if, in addition to rules of contract and other principles of the general law (including equity), a statutory body of this type, which is after all exercising a trading function, should also be subject to judicial review. ... Any trading organisation subjected to this requirement would be at a distinct competitive disadvantage.

In light of Mercury, the way in which such an "intolerable" situation is to be dealt with is not by denying any possibility of review of the contractual and/or trading activities of statutory and other public bodies, but rather by only subjecting those activities to grounds of review which are appropriate in the circumstances.

120 Chen above n 117, 298. 
and Best, however, have argued that one ought not to read too much into Lord Templeman's restrictive statements of grounds for review. They note that his statement reflects what is likely but does not rule out that in an appropriate case the unlikely could happen and a more rigorous review of decisions to enter or determine contracts occur, particularly where procedural impropriety or illegality is involved. ${ }^{121}$ Indeed, in his separate concurring judgment in the very recent Vector Ltd $v$ Transpower, Thomas J expressed the view that Lord Templeman's statement should not be read as precluding challenges on grounds of illegality, improper purpose or motive, or discriminatory practices. ${ }^{122}$

These cases illustrate the important point that determining that a case is a public law one does not determine the extent to which public law considerations will intrude. Whether a case is a public law one is merely a threshold issue. The Mercury approach would seem to indicate preference for a reasonably low threshold, tempered by relatively narrow grounds of review in relation to some of the new matters which the wide jurisdiction brings before the courts. Later decisions have not always appeared to fully understand this balance in Mercury. In a number of cases the High Court would appear to have ruled out any jurisdiction to review a commercial contract entered into by a public body because of the supposed absence of a statutory power in making the contract. While space constraints do not permit consideration of those cases, ${ }^{123}$ it is important to emphasise that insofar as they suggest that review is precluded by the commerciality of the decision involved, they are flawed. As Richard Best states in an article in LawTalk, "Rationalising judicial review of commercial decisions",124 "'Commercial' should not automatically be equated with 'private' or 'not reviewable'."

\section{CONCLUSION}

The purpose of this paper has been to show that:

(1) in particular, the broad application provisions in the Bill of Rights suggest that public law standards will be relevant to many aspects of both statutory and common law "private law";

$121 \mathrm{P}$ Radich and R Best "Maximising the Benefit from Administrative Law Litigation" AIC Administrative Law Summit, Wellington 17-18 April 1997, 12.

122 Vector Ltd $v$ Transpower [1999] 3 NZLR 646, 671, paras 85-6.

123 They are considered at some length by Radich and Best, above $\mathrm{n} 15$.

124 Richard Best "Rationalising Judicial Review of Commercial Decisions" (October 1997) 487 LawTalk 20. 
(2) there is also the possibility that the ambit of certain "private law" concepts may have to be extended if there is to be compliance with the Bill of Rights (for example section 21 Bill of Rights may require the development of the tort of privacy);

(3) though current jurisprudence has not really examined the issue, there is Canadian authority to support the view that if a broad interpretation is given to section 3(a) of the Bill of Rights, SOEs and other Crown entities could be subject to the Bill of Rights in relation to all acts which they do, from the performance of their public functions to internal matters;

(4) there is confusion as to the applicability of the Bill of Rights to the commercial activities of SOEs and Crown entities under section 3(b), although the preponderance of authority indicates that such activities will be caught;

(5) private entities will also be caught by the Bill of Rights to the extent that their activities involve the performance of public functions, duties or powers. The extent to which the Bill of Rights applies to private businesses operating under licence is an open issue with substantial ramifications;

(6) even in the traditional field of public law, judicial review, developments are apace which indicate the importance of the public nature of the function (as opposed to the public character of the entity) which is impugned in determining whether public law judicial review is available. Recent case law indicates that the Courts are quite prepared to apply public law constraints to private entities where such entities are regarded as exercising public power or discharging public functions;

(7) at the same time the case law establishes that the public status of a body is sufficient reason as to why its commercial decisions are in principle subject to judicial review, even if the grounds of review of such decisions are limited.

In light of these propositions the broad conclusion can be drawn, and needs to be appreciated, that a "public law" case can arise in settings far removed from those traditionally thought of as "public law" ones. Private lawyers of the future will need to have strong awareness of public law issues to practice effectively; but equally we public lawyers need to start extending our horizons and to become comfortable with the emerging reality of the considerable substantive interaction between public and private law. 